Article

\title{
Friedel-Craft Acylation of ar-Himachalene: Synthesis of Acyl-ar-Himachalene and a New Acyl-Hydroperoxide
}

\author{
Issam Hossini ${ }^{1}$, Mohamed Anoir Harrad ${ }^{1}$, Mustapha Ait Ali ${ }^{1}$, Larbi El Firdoussi ${ }^{1}$, \\ Abdallah Karim ${ }^{1}$, Pedro Valerga ${ }^{2, *}$ and M. Carmen Puerta ${ }^{2}$
}

1 Laboratoire de Chimie de Coordination, Faculté des Sciences-Semlalia BP 2390, Marrakech 40001, Morocco; E-Mails: houssiniissam@yahoo.fr (I.H.); ma.harrad@yahoo.fr (M.A.H.); aitali@ucam.ac.ma (M.A.A.); elfirdoussi@ucam.ac.ma (L.E.F.); karim@ucam.ac.ma (A.K.)

2 Departamento de CMIM y Química Inorgánica, Facultad de Ciencias, Universidad de Cadiz, Campus Universitario Río San Pedro, Puerto Real 11510, Spain; E-Mail: carmen.puerta@uca.es (M.C.P.)

* Author to whom correspondence should be addressed; E-Mail: pedro.valerga@uca.es; Tel.: +34 956 016340; Fax: +34956016288.

Received: 19 May 2011; in revised form: 29 June 2011 / Accepted: 8 July 2011 /

Published: 14 July 2011

\begin{abstract}
Friedel-Craft acylation at $100{ }^{\circ} \mathrm{C}$ of 2,5,9,9-tetramethyl-6,7,8,9-tetrahydro-5 $\mathrm{H}$ benzocycloheptene [ar-himachalene (1)], a sesquiterpenic hydrocarbon obtained by catalytic dehydrogenation of $\alpha$-, $\beta$ - and $\gamma$-himachalenes, produces a mixture of two compounds: (3,5,5,9-tetramethyl-6,7,8,9-tetrahydro-5H-benzocyclohepten-2-yl)-ethanone (2, in $69 \%$ yield), with a conserved reactant backbone, and 3, with a different skeleton, in $21 \%$ yield. The crystal structure of 3 reveals it to be 1-(8-ethyl-8-hydroperoxy-3,5,5trimethyl-5,6,7,8-tetrahydronaphthalen-2-yl)-ethanone. In this compound $\mathrm{O}-\mathrm{H} . . \mathrm{O}$ bonds form dimers. These hydrogen-bonds, in conjunction with weaker C-H...O interactions, form a more extended supramolecular arrangement in the crystal.
\end{abstract}

Keywords: ar-himachalene; Friedel-Craft acylation; hydroperoxyde; hydrogen-bonds 


\section{Introduction}

Atlas Cedar (Cedrus atlantica) is the principal species in Moroccan forests. The tree plays a significant role in the socio-economy of Morocco, being good for furniture making. Furthemore, Atlas cedarwood oils are constituents of several products such as drugs, perfumes etc. [1-6]. The essential oil is mainly composed of the sesquiterpene hydrocarbons $\alpha$-himachalene, $\beta$-himachalene, and $\gamma$-himachalene (Figure 1) which together can make up almost $70 \%$ of the composition [7,8] Ar-Himachalene (Figure 1), valued in perfumery [1,7] and the male-produced pheromone component of the flea beetle Aphthona flava $[9,10]$, constitutes only $0.5 \%$ of the total oil.

Essential oils are an extremely useful source of starting materials for several industrial processes used for the synthesis of fragances and pharmaceutical compounds. A new route to high added value compounds from these cheap natural products is therefore a challenge, among which catalytic functionalization is of major interest. In fact, many different methods for functionalization of this essential oil were developed by our group within the framework of preparing new products having olfatory properties [11-18].

Figure 1. Main components of cedarwood oil.

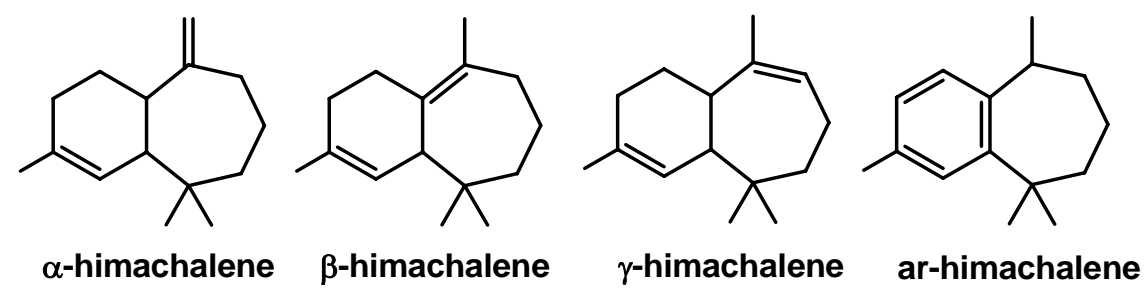

Several publications are devoted to the synthesis of new chiral ketone-peroxides, which play an important role in organic synthesis as substrates for the preparation of many classes of compounds such as chiral aromatic alcohols [19] or Schiff base [20] derivatives. As a contribution to this widespread area, we describe herein the synthesis and characterization of a new functionalized peroxide which could be a useful starting material for the preparation of new aromatic musk odorants $[21,22]$.

\section{Results and Discussion}

In the first step of our procedure, ar-himachalene (1) was prepared in good yield by dehydrogenation of the mixture of $\alpha$-, $\beta$ - and $\gamma$-himachalene using the previously published method [23]. The reaction, catalyzed with Raney nickel, affords ar-himachalene in 93\% yield.

In the second step of the procedure (Scheme 1), Friedel-Craft acylation of ar-himachalene with acetyl chloride at room temperature, using $\mathrm{AlCl}_{3}$ as catalyst, gave 1-(3,5,5,9-tetramethyl-6,7,8,9tetrahydro-5H-benzocyclohepten-2-yl)-ethanone (2) as single product. When this reaction was carried out at $100{ }^{\circ} \mathrm{C}$, keeping other conditions constant, 2 as major product (69\%) and 1-(8-ethyl-8hydroperoxy-3,5,5-trimethyl-5,6,7,8-tetrahydro-naphthalen-2-yl)-ethanone (3, in $21 \%$ yield) were obtained. 
The spectroscopic data of the two newly prepared products $\mathbf{2}$ and $\mathbf{3}$ are consistent with the assigned structures, characterized in ${ }^{1} \mathrm{H}-0$ and ${ }^{13} \mathrm{C}-\mathrm{NMR}$ spectroscopies by the existence of only two $\mathrm{CH}$ aromatic signals, which appeared as singlets, at $7.10 \mathrm{ppm}$ and $7.50 \mathrm{ppm}$ for 2 and at $7.09 \mathrm{ppm}$ and $7.71 \mathrm{ppm}$ for 3 . The methyl moiety of the acetyl groups appeared at $2.50 \mathrm{ppm}$ and $2.48 \mathrm{ppm}$ for 2 and 3 , respectively. The rearrangement of the seven membered ring in compound $\mathbf{3}$, is shown by the presence of ethyl group signals at $0.85 \mathrm{ppm}\left(\mathrm{CH}_{2} \mathrm{CH}_{3}, \mathrm{~d}, J=7.5 \mathrm{~Hz}\right)$ and $1.85 \mathrm{ppm}\left(\mathrm{CH}_{2} \mathrm{CH}_{3}, \mathrm{q}\right.$, $J=7.5 \mathrm{~Hz}$ ). These assignments are in agreement with the ${ }^{13} \mathrm{C}-\mathrm{NMR}$ data. In the ${ }^{1} \mathrm{H}-\mathrm{NMR}$ of compound 3 a signal at $2.12 \mathrm{ppm}$ attributable to $\mathrm{OOH}$ was found. Its relative sharpness points out the participation of the hydroperoxide group in hydrogen-bonds.

Scheme 1. Friedel-Craft acylation of ar-himachalene.

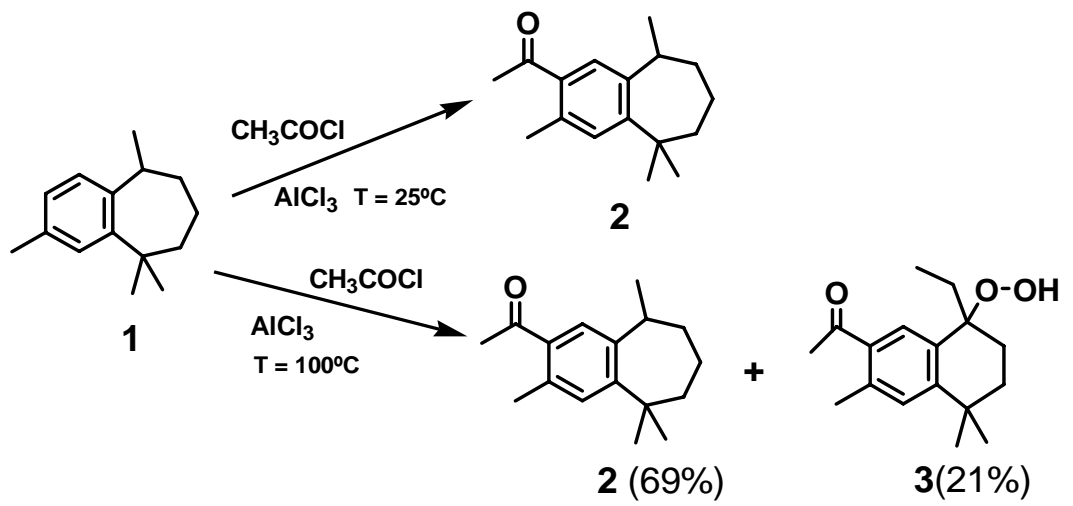

The formation of this new acyl-hydroperoxyde 3 can be explained by the oxyfunctionalization of acyl-ar-himachalene with molecular oxygen when exposed to air, as described by Orfanopoulos et al. [24]. Scheme 2 shows the proposed mechanism. The molecular oxygen [2 +2$]$ ene reaction of the product $\mathrm{A}^{\prime}$ (probably formed in situ at $100{ }^{\circ} \mathrm{C}$ as a consequence of the basicity of $\mathrm{AlCl}_{4}{ }^{-}$) gives intermediate B', which was converted to the transition state C' [24]. Rearrangement of the transition state C' gives the hydroperoxide 3 . We note here that the derivatives of himachalene with seven-membered rings are susceptible to undergo rearrangements. Recently, Gouygou et al. [25,26] have reported the reactivity of epoxides derived from the sesquiterpenic himachalenes in the presence of Lewis or Bronsted acids which catalyze the rearrangement of the ring-opening reactions to give ketones or aldehydes through the formation of carbocations.

Scheme 2. A possible mechanism for the formation of acyl-hydroperoxide (3).

$\mathrm{CH}_{3} \mathrm{COCl}+\mathrm{AlCl}_{3} \longrightarrow \mathrm{CH}_{3} \mathrm{CO}^{+}, \mathrm{AlCl}_{4}^{-}$<smiles>CCCCC(C)(C)c1cc(C)ccc1C(C)C</smiles>

1<smiles>CC(=O)c1cc2c(cc1C)C(C)(C)CC[C@@H]2C</smiles>

2<smiles></smiles>

A'<smiles>CC(=O)c1cc2c(cc1C)C(C)(Br)CC[C@@H]1OO[C@@]1(O)C2(C)C[18O]</smiles>

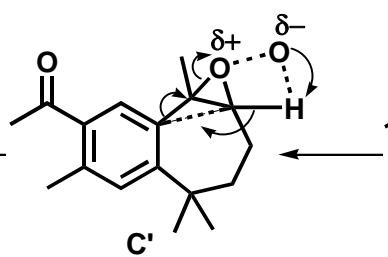


The X-ray single crystal structure analysis permits us to confirm the structure of the rearranged product 3 (Figure 2). Selected bond lengths $(\AA)$ and angles $\left(^{\circ}\right)$ are given in Table 1.

Figure 2. ORTEP drawing (50\% thermal ellipsoids) of 3.

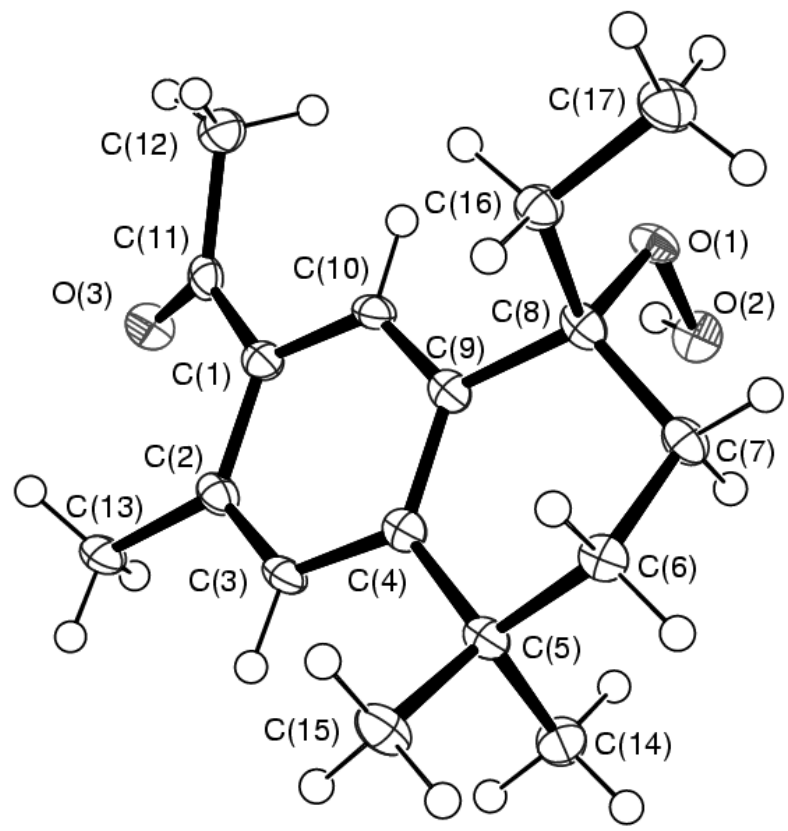

Table 1. Selected bond lengths $(\AA)$ and angles $\left(^{\circ}\right)$ for 3 (e.s.d.s in parentheses).

\begin{tabular}{|ll|ll|}
\hline $\mathrm{O}(1)-\mathrm{O}(2)$ & $1.462(3)$ & $\mathrm{O}(1)-\mathrm{C}(8)-\mathrm{C}(9)$ & $109.8(2)$ \\
$\mathrm{O}(1)-\mathrm{C}(8)$ & $1.452(3)$ & $\mathrm{O}(1)-\mathrm{C}(8)-\mathrm{C}(16)$ & $102.4(2)$ \\
$\mathrm{O}(3)-\mathrm{C}(11)$ & $1.232(3)$ & $\mathrm{O}(1)-\mathrm{C}(8)-\mathrm{C}(7)$ & $110.2(2)$ \\
$\mathrm{O}(2)-\mathrm{O}(1)-\mathrm{C}(8)$ & $108.73(19)$ & $\mathrm{O}(3)-\mathrm{C}(11)-\mathrm{C}(1)$ & $120.8(3)$ \\
\hline
\end{tabular}

The formation from ar-himachalene of a new bicyclic 1,2,3,4-tetrahydronaphthalene is observed. Although the $\mathrm{C}(8)$ asymmetric center has the $R$-configuration in the molecule shown in Figure 2, the existence of a center of symmetry in space group $\mathrm{P} 2{ }_{1} / \mathrm{n}$ corroborates the formation of a racemic mixture. A bond length of 1.462(3) $\AA$ has been found for the hydroperoxide, corresponding to a single bond O-O. It compares well with other hydroperoxides [27-31]. Bond lengths and angles around C(8) show its $\mathrm{sp}^{3}$ character. On the other hand, the environment of $\mathrm{C}(11)$ in the acyl group shows its usual $\mathrm{sp}^{2}$ geometry. In addition to demonstrating the nature of these functional groups and the new skeleton with two six membered condensed rings instead of ar-himachalene, the crystal structure also reveals the existence of intra- and intermolecular hydrogen-bonds (Table 2). The strongest of these interactions contributes to form dimers (Figure 3).

Table 2. Hydrogen-Bonds (lengths in $\AA$, angles in ${ }^{\circ}$ ) for 3 (e.s.d.s in parentheses).

\begin{tabular}{|l|l|l|l|l|l|}
\hline D--H..A & d(D--H) & d(H..A) & d(D....A) & angle (D--H..A) & Symmetry label \\
\hline $\mathrm{O}(2)--\mathrm{H}(2 \mathrm{~A}) . . \mathrm{O}(3)$ & 0.8400 & 1.9400 & $2.765(3)$ & 165.00 & 35556 \\
$\mathrm{C}(3)--\mathrm{H}(3) . . \mathrm{O}(1)$ & 0.9500 & 2.4800 & $3.321(4)$ & 147.00 & 45555 \\
$\mathrm{C}(7)--\mathrm{H}(7 \mathrm{~B}) . . \mathrm{O}(2)$ & 0.9900 & 2.3700 & $2.806(4)$ & 106.00 & intramolecular \\
\hline
\end{tabular}


Figure 3. Molecular dimers formed by two hydrogen-bonds with a total bond length between donor $\mathrm{O}(2)$ and acceptor $\mathrm{O}(3)$ of 2.765(3) A.

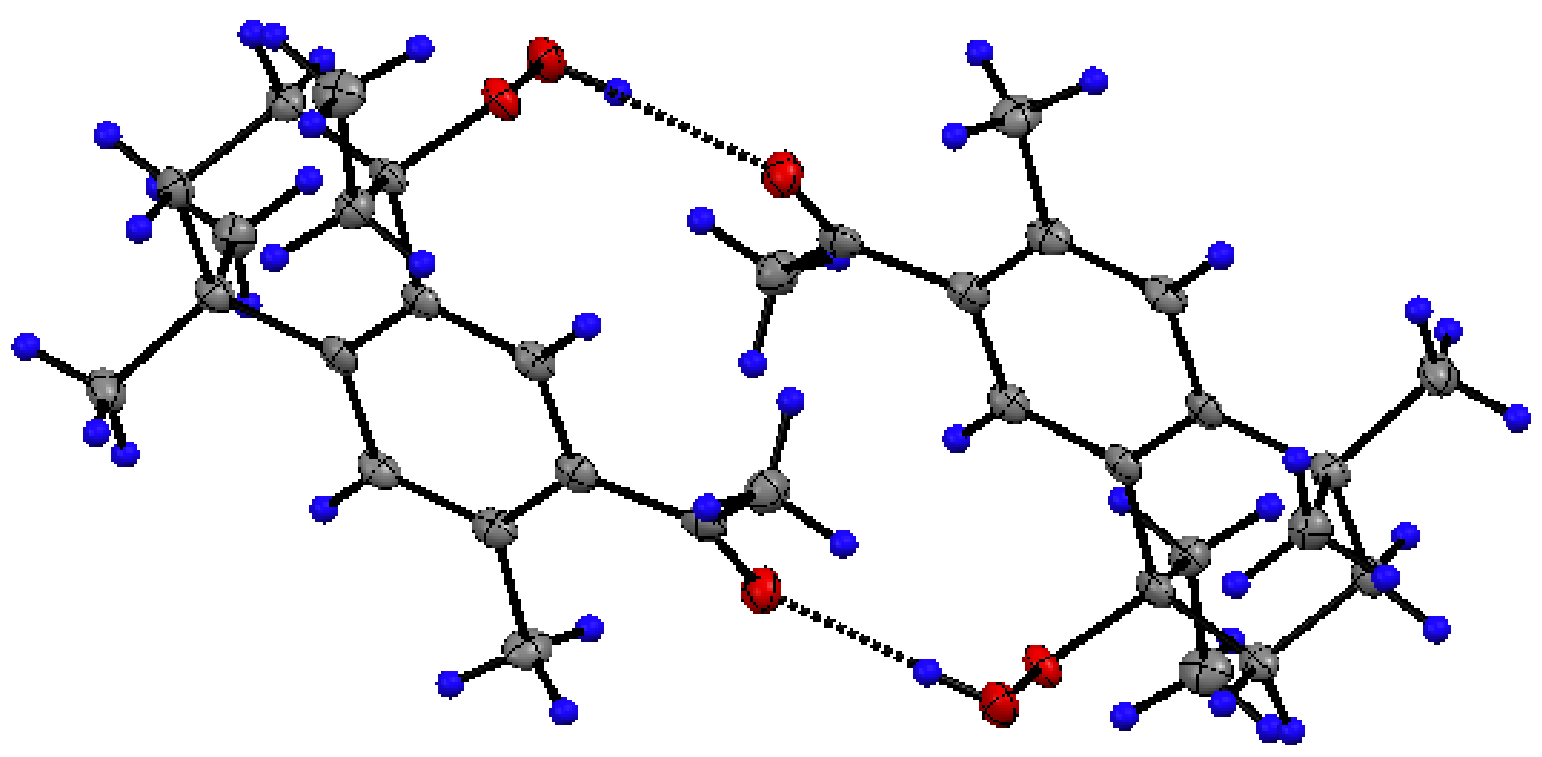

The association of two molecules is also enhanced by a $\mathrm{C}(7)--\mathrm{H}(7 \mathrm{~B}) . . \mathrm{O}(2)$ intramolecular interaction. The dimer adopts an overall conformation in which the rings are oriented parallel to each other.

A second weaker intermolecular hydrogen-bond, $\mathrm{C}(3)-\mathrm{H} . . . \mathrm{O}(1) 3.321(4) \AA$, is responsible for the interaction between the first one and other dimers forming chains of indefinite length. In this hydrogen-bond the internal hydroperoxide oxygen atom $\mathrm{O}(1)$ acts as acceptor. The whole hydrogenbonded scheme involves most of all potential proton donors and acceptors. An useful way to define a hydrogen-bond pattern is the graph set [32]. In our case, the morphology of hydrogen-bonded array is shown in Figure 4, where the intramolecular hydrogen-bond has been suppressed for clarity.

Figure 4. Hydrogen-bond patterns.

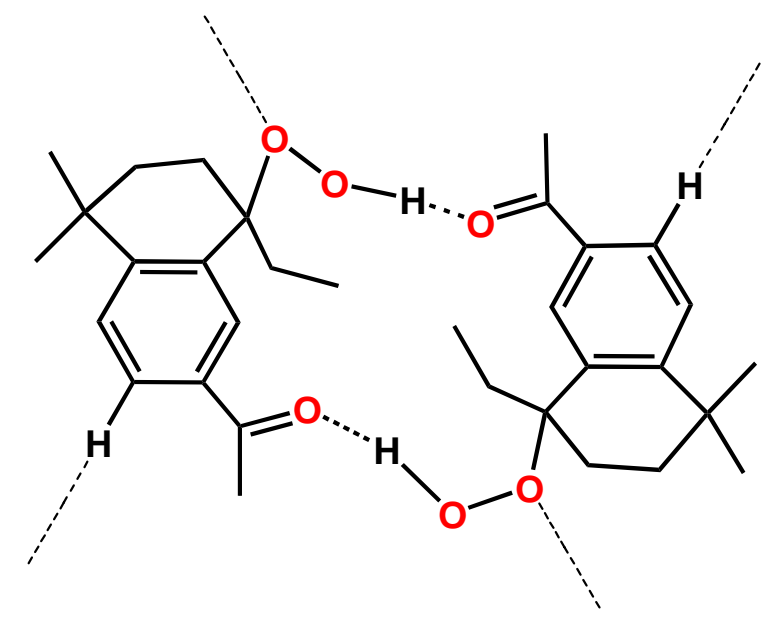

Through this interaction each dimer is bonded to four other bimolecular sets. The global effect of all the described intermolecular interactions is a supramolecular arrangement in columns. These rows form layers aligned to the $\left(\begin{array}{lll}-1 & 0 & 1\end{array}\right)$ plane (Figure 5$)$. 
Figure 5. Layers of molecular rows aligned to the $\left(\begin{array}{lll}-1 & 0 & 1\end{array}\right)$ plane.

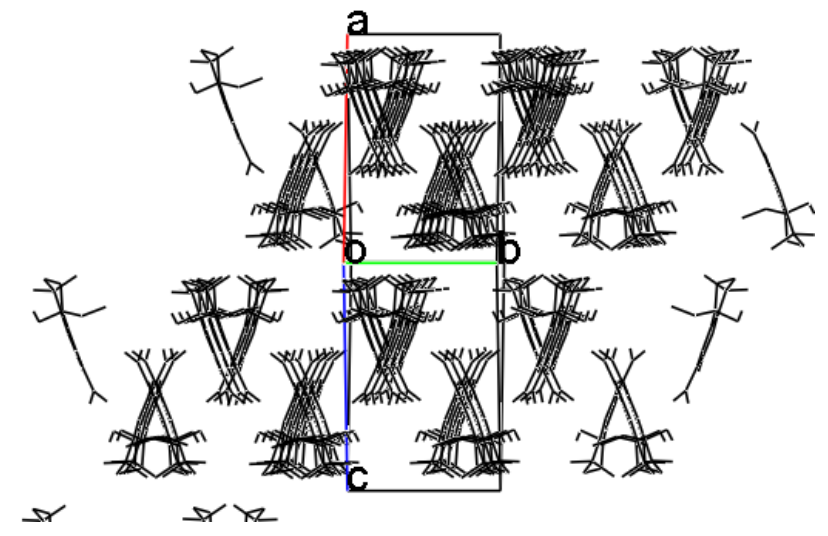

\section{Experimental}

\subsection{General}

NMR studies were performed on a Bruker Avance 300 spectrometer in $\mathrm{CDCl}_{3}$, chemicals shifts are given in ppm relative to external TMS and coupling constant $(J)$ in Hz. Liquid chromatography was performed on silica gel (Merk 60, 220-440 mesh; eluent: hexane/ethylacetate). All the reagents and solvents used in the experiments were purchased from commercial sources as received without further purification (Aldrich, Fluka, Acros), and Ar-himachalene were prepared by our team [23].

\subsection{General Acylation Procedure:}

Acyl chloride (1.56 mmol, $0.122 \mathrm{~g})$ and $\mathrm{AlCl}_{3}(1.87 \mathrm{mmol}, 0.25 \mathrm{~g})$ were mixed in nitromethane $(10 \mathrm{~mL})$, and heated at $100{ }^{\circ} \mathrm{C}$. The aromatic compound $(1 \mathrm{mmol})$ was added to the mixture and the progress of the reaction was monitored by TLC. At the end of the reaction, the solvent was evaporated on a rotary evaporator and a saturated solution of $\mathrm{NaHSO}_{4}(20 \mathrm{~mL})$ was added. The crude material was extracted with $\mathrm{Et}_{2} \mathrm{O}(3 \times 10 \mathrm{~mL})$ and dried over anhydrous $\mathrm{MgSO}_{4}$. Evaporation of the solvent afforded the crude products which were separated by column chromatography using hexane/ethyl acetate (8/2). The products were obtained in yields of $69 \%$ for 2 and $21 \%$ for isolated 3.

\subsection{Acyl-Ar-Himachalene 2:}

Pale yellow oil, NMR ${ }^{1} \mathrm{H}\left(\mathrm{CDCl}_{3}\right), \delta$ ppm: $1.24\left(3 \mathrm{H}, \mathrm{s}, \mathrm{CH}_{3}\right), 1.32\left(3 \mathrm{H}, \mathrm{d}, J=6.9, \mathrm{CH}_{3}\right), 1.36(3 \mathrm{H}$, $\left.\mathrm{s}, \mathrm{CH}_{3}\right), 1.40-1.45$ (1 H, m, CHH), 1.54-1.57 (1 H, m, CHH), 1.67-1.74 (4 H, m, CH $), 2.44(3 \mathrm{H}, \mathrm{s}$, $\left.\mathrm{CH}_{3}\right), 2.48\left(3 \mathrm{H}, \mathrm{s}, \mathrm{ArCH}_{3}\right), 3.20\left(1 \mathrm{H}, \mathrm{m}, \mathrm{CHCH}_{3}\right), 7.14\left(1 \mathrm{H}, \mathrm{s}, \mathrm{C} 4_{\mathrm{ar}}-H\right), 7.49\left(1 \mathrm{H}, \mathrm{s}, \mathrm{C}_{\mathrm{ar}}-\mathrm{H}\right)$; $\mathrm{NMR}{ }^{13} \mathrm{C}\left(\mathrm{CDCl}_{3}\right): 19.82,20.61,22.73,27.95,28.54,32.67,33.21,35.24,38.61,39.74,125.97$, $129.57,133.70,134.98,140.03,150.42,198.79$.

\subsection{Acyl-Hydroperoxyde 3:}

White solid, ${ }^{1} \mathrm{H}-\mathrm{NMR}\left(\mathrm{CDCl}_{3}\right), \delta$ ppm: $0.85\left(3 \mathrm{H}, \mathrm{t}, \mathrm{J}=7.5 \mathrm{~Hz}, \mathrm{CH}_{2} \mathrm{CH}_{3}\right), 1.20\left(3 \mathrm{H}, \mathrm{s}, \mathrm{C}\left(\mathrm{CH}_{3}\right)_{2}\right)$, $1.22\left(3 \mathrm{H}, \mathrm{s}, \mathrm{C}\left(\mathrm{CH}_{3}\right)_{2}\right), 1.55-1.65(1 \mathrm{H}, \mathrm{m}, \mathrm{HCH}), 1.71-1.74(1 \mathrm{H}, \mathrm{m}, \mathrm{HCH}), 1.81(2 \mathrm{H}, \mathrm{q}, J=7.5 \mathrm{~Hz}$, $\left.\mathrm{CH}_{2} \mathrm{CH}_{3}\right), 1.87-1.97(1 \mathrm{H}, \mathrm{m}, \mathrm{HCH}), 2.12(1 \mathrm{H}, \mathrm{s}, \mathrm{OOH}), 2.25-2.39(1 \mathrm{H}, \mathrm{m}, \mathrm{HCH}), 2.43(3 \mathrm{H}, \mathrm{s}$, 
$\left.\mathrm{C}_{\mathrm{ar}}-\mathrm{CH}_{3}\right), 2.47\left(3 \mathrm{H}, \mathrm{s}, \mathrm{COCH}_{3}\right), 7.09\left(1 \mathrm{H}, \mathrm{s}, \mathrm{C}_{\mathrm{ar}}-\mathrm{H}\right), 7.72\left(1 \mathrm{H}, \mathrm{s}, \mathrm{Cl}_{\mathrm{ar}}-\mathrm{H}\right) ;{ }^{13} \mathrm{C}-\mathrm{NMR}\left(\mathrm{CDCl}_{3}\right): 8.62$, 21.85, 25.23, 29.31, 31.04, 31.33, 32.19, 34.16, 35.30, 84.65, 128.34, 130.24, 133.70, 134.40, 138.03, 151.28, 199.50 .

\subsection{X-ray Structure Determination}

Single crystals of compound $\mathbf{3}$ were obtained and mounted on glass fiber to carry out the crystallographic study. Crystal data and experimental details are given in Table 3. X-ray diffraction data collection was measured at $100 \mathrm{~K}$ on a Bruker Smart APEX CCD 3-circle diffractometer using a sealed tube source, graphite monochromated Mo Ka radiation $(\lambda=0.71073 \AA)$ at the Servicio Central de Ciencia y Tecnología de la Universidad de Cádiz. Four sets of frames were recorded over a hemisphere of the reciprocal space by omega scan with $\delta(\omega) 0.30$ degrees and exposure of 10 seconds per frame. Correction for absorption was applied by scans of equivalents using program SADABS [33]. An insignificant crystal decay correction was also applied. The structure was solved by direct methods, completed by subsequent difference Fourier syntheses and refined on F2 by full matrix least-squares procedures using the programs contained in SHELXTL package [34] Non hydrogen atoms were refined with anisotropic displacement parameters. The program ORTEP-3 was used for plotting [35]. Crystallographic data in CIF format for $\mathbf{3}$ have been deposited at Cambridge Crystallographic Data System with reference CCDC 752508.

Table 3. Crystal Data and Details of the Structure Determination for Compound 3.

\begin{tabular}{|c|c|}
\hline Formula & $\mathrm{C}_{17} \mathrm{H}_{24} \mathrm{O}_{3}$ \\
\hline Formula Weight & 276.36 \\
\hline Crystal System & Monoclinic \\
\hline Space group & $\mathrm{P} 2_{1} / \mathrm{n}($ No. 14$)$ \\
\hline $\mathrm{a}, \mathrm{b}, \mathrm{c}(\AA)$ & $14.459(9), 8.166(5), 14.459(9)$ \\
\hline$\alpha, \beta, \gamma\left(^{\circ}\right)$ & $90,115.50(2), 90$ \\
\hline $\mathrm{V}\left(\AA^{3}\right)$ & $1540.9(17)$ \\
\hline $\mathrm{Z}$ & 4 \\
\hline $\mathrm{d}($ calc $)\left(\mathrm{g} / \mathrm{cm}^{3}\right)$ & 1.191 \\
\hline$\mu(\operatorname{MoK} \alpha)\left(\mathrm{mm}^{-1}\right)$ & 0.080 \\
\hline $\mathrm{F}(000)$ & 600 \\
\hline Crystal Size (mm) & $0.27 \times 0.54 \times 0.56$ \\
\hline Temperature (K) & 100 \\
\hline Radiation, $\lambda(\AA)$ & MoK $\alpha, 0.71073$ \\
\hline$\theta \operatorname{Min}-\operatorname{Max}\left({ }^{\circ}\right)$ & $1.7,25.0$ \\
\hline Dataset (h, k, 1 ranges) & $-17: 16 ;-9: 7 ;-17: 17$ \\
\hline Tot., Uniq. Data, R(int) & $7525,2657,0.188$ \\
\hline Observed data $[\mathrm{I}>2.0 \sigma(\mathrm{I})]$ & 2236 \\
\hline Nref, Npar & 2657,187 \\
\hline $\mathrm{R}, \mathrm{wR}_{2}, \mathrm{~S} *$ & $0.0703,0.1937,1.06$ \\
\hline Max. and Av. Shift/Error & $0.000,0.000$ \\
\hline Min. and Max. Resd. Dens. (e/A $\left.{ }^{3}\right)$ & $-0.31,0.31$ \\
\hline
\end{tabular}




\section{Conclusions}

Following our studies on the suitable use of natural resources in order to obtain products of high added value, in the present work we have shown that the Friedel-Crafts acylation of ar-himachalene, under mild conditions, at $25^{\circ} \mathrm{C}$, produces (3,5,5,9-tetramethyl-6,7,8,9-tetrahydro- $5 \mathrm{H}$ benzocyclohepten-2-yl)-ethanone (2). However, at $100{ }^{\circ} \mathrm{C}$, the Friedel-Crafts reaction leads to a mixture of two compounds: (3,5,5,9-tetramethyl-6,7,8,9-tetrahydro-5H-benzocyclohepten-2-yl)ethanone $(2,69 \%)$, in which the backbone of reactant is conserved, and 1-(8-ethyl-8-hydroperoxy3,5,5-trimethyl-5,6,7,8-tetrahydronaphthalen-2-yl)-ethanone $(3,21 \%)$. In the solid state this new hydroperoxy compound forms dimers by hydrogen-bonds. These dimers are grouped in extended pattern by weaker hydrogen-bonds.

\section{Acknowledgements}

We thank to the SCCYT (Universidad de Cádiz) for X-ray data collection and the Consejería de Innovación, Ciencia y Empresa de la Junta de Andalucía for financial support.

\section{References}

1. Adams, R.P. Cedar Wood oil-analysis and properties. In Modern Methods of Plant Analysis, New Series, Vol. 12, Essential Oils and Waxes; Linskens, H.F., Jackson, J.F., Eds.; Springer-Verlag: New York, NY, USA, 1991; pp. 159-173.

2. Digrak, M.; Ilcim, A.; Hakki, A.M. Antimicrobial activities of several parts of Pinus brutia, Juniperus oxycedrus, Abies Cilicia, Cedrus libani and Pinus nigra. Phytother. Res. 1999, 13, 584-587.

3. Singh, D.; Rao, S.M.; Tripathi, A.K. Cedarwood oil [Cedrus deodara] as a potential insecticidal agent against mosquitoes. Naturwissenschaften 1984, 71, 265-266.

4. Walker, G.T. Cedarwood oil. Perfum. Essent. Oil Rec. 1968, 59, 347-350.

5. Lawrence, B.M. Cedarwood oil. Perfum. Flavor. 1980, 5, 63.

6. Mori, K. Recent results in the synthesis of ecologically important bioregulators. Pure Appl. Chem. 2001, 73, 601-606.

7. Chalchat, J.-C.; Garry, R.-P.; Michet, A. Essential oil in sawdust of Cedrus atlantica from Morocco. JOER 1994, 6, 323-325.

8. Balchin, L. Relationship between bioactivity and chemical composition of commercial essential oils. Flavour Fragrance J. 1998, 13, 98-104.

9. Bartelt, R.J.; Cossé, A.A.; Zilkowski, B.W.; Weisleder, D.; Momany, F.A. Male-specific sesquiterpenes from Phyllotreta and Aphthona flea beetles. J. Chem. Ecol. 2001, 27, 2397-2423.

10. Mori, K. Synthesis of (R)-ar-turmerone and its conversion to (R)-ar-himachalene, a pheromone component of the flea beetle: (R)-ar-himachalene is dextrorotatory in hexane, while levorotatory in chloroform. Tetrahedron: Asymmetry 2005, 16, 685-692.

11. El Firdoussi, L.; Benharref, A.; Allaoud, S.; Karim, A.; Castanet, Y.; Mortreux, A.; Petit, F. Palladium(II)-catalyzed acetoxylation and methoxylation of olefinic terpenes. J. Mol. Catal. 1992, 72, L1-L5. 
12. El Firdoussi, L.; Baqqa, A.; Allaoud, S.; Ait Allal, B.; Karim, A.; Castanet, Y.; Mortreux, A. Selective palladium-catalyzed functionalization of limonene: synthetic and mechanistic aspects. J. Mol. Catal. A: Chem. 1998, 135, 11-22.

13. Ait Allal, B.; El Firdoussi, L.; Allaoud, S.; Karim, A.; Castanet, Y.; Mortreux, A. J. Mol. Catal. A: Chem. 2000, 200, 177-184.

14. Ziyat, H.; El Houssame, S.; Ait Ali, M.Y.; Ait Itto, M.; Karim, A.; Wartchow, R.; Butenschon, H. Synthesis, structure, and absolute configuration of a new cyclopropanic compound derived from the sesquiterpene $\beta$-himachalene. Z. Naturforsch. 2004, 59b, 1177-1179.

15. Ziyat, H.; Ait Ali, M.; Karim, A.; Meliet, C.; Castanet, Y.; Mortreux, A. Acta Chim. Slov. 2004, 51, 223-230.

16. Ziyat, H.; Ait Itto, M.Y.; Ait Ali, M.; Riahi, A.; Karim, A.; Daran, J.-C.; Arkivoc 2006, xii, 152-160.

17. Feddouli, A.; Ait Itto, M.Y.; Ait Ali, M.; Hasnaoui, A.; Riahi, A. Efficient Approach for the synthesis of novel functionalized isoxazolines from limonene. Synth. Commun. 2006, 36, 3617-3624.

18. El Firdoussi, L.; Ait Ali, M.; Karim, A.; Spannenberg, A. Zeitschrift Kristallographie 2007, NCS 222, 195-196.

19. Mévellec, V.; Mattioda, C.; Schulz, J.; Rolland, J.P.; Roucoux, A. Enantioselective hydrogenation of ethyl pyruvate in biphasic liquid-liquid media by reusable surfactant-stabilized aqueous suspensions of platinum nanoparticles. J. Catal. 2004, 225, 1-6.

20. Gao, W.T.; Zheng, Z. Synthesis and characterization of chiral nitrobenzaldehyde-schiff base ligands. Molecules 2003, 8, 788-792.

21. Fehr, C.; Chaptal-Gradoz, N.C. Syntheses of the enantiomers of vulcanolide. Helv. Chim. Acta 2002, 85, 533-543.

22. Fehr, C.; Chaptal-Gradoz, N.; Galindo, J. Synthesis of (-)-Vulcanolide by enantioselective protonation. Chem. Eur. J. 2002, 8, 853-858.

23. Abouhamza, B.; Allaoud, S.; Karim, A. 2,4-Dimethyl-3-phenyl-[2'-methyl-3'-chloro]-7-chloro-8methyl-1,3-diaza-2,4-diboranaphtalene Tricarbonylchromium Complexes. Molecules 2001, 6, M211.

24. Alberti, M.N.; Orfanopoulos, M. Stereoelectronic and solvent effects on the allylic oxyfunctionalization of alkenes with singlet oxygen. Tetrahedron 2006, 62, 10660-10675.

25. El Haib, A.; Benharref, A.; Parrès-Maynadié, S.; Manoury, E.; Daran, J.-C.; Urrutigoïty, M.; Gouygou, M. Molecular rearrangement of epoxide derived from sesquiterpenes by Lewis acid catalysis. Tetrahedron: Asymmetry 2010, 21, 1272-1277.

26. El Haib, A.; Benharref, A.; Parrès-Maynadié, S.; Manoury, E.; Urrutigoïty, M.; Gouygou, M. Lewis acid- and Bronsted acid-catalyzed stereoselective rearrangement of epoxides derived from himachalenes: Access to new chiral polycyclic structures. Tetrahedron: Asymmetry 2011, 22, 101-108.

27. Lee, K.-H.; Nozaki, H.; McPhail, A.T. Structure and stereochemistry of maytensifolin-a, a novel hydroperoxy-nortriterpene from maytenus diversifolia. Tetrahedron Lett. 1984, 25, 707-710.

28. Perales, A.; Piozzi, F. The X-ray revised stereochemistry of the hydroperoxide of atractyligenin. Z. Kristallogr. 1989, 188, 255-259. 
29. Bernat, V.; André-Barrès, C.; Baltas, M.; Saffon. N.; Vial, H. Synthesis of antimalarial G-factors endoperoxides: Relevant evidence of the formation of a biradical during the autoxidation step. Tetrahedron 2008, 64, 9216-9224.

30. Griesbeck, A.G.; Lex, J.; Saygin, K.M.; Steinwascher, J. Azidohydroperoxidation of pinenes: stereoselectivity pattern and the first X-ray structure of a 2-azidohydroperoxide. Chem. Commun. 2000, 2205-2206, doi: 10.1039/B005834N.

31. Khrustalev; Antipin, N.Yu.; Kosnikov, A.Yu.; Antonovsky, V.L. Krystallografiya. Crystallogr. Rep. 2004, 49, 860.

32. Etter, M.C. Encoding and decoding hydrogen-bond patterns of organic compounds. Acc. Chem. Res. 1990, 23, 120-126.

33. Sheldrick, G.M. SADABS; University of Göttingen, Göttingen, Germany, 2001.

34. Sheldrick, G.M. SHELXTL, Version 6.10, Crystal Structure Analysis Package; Bruker AXS: Madison, WI, USA, 2000.

35. Farrugia, L.J. ORTEP-3 for Windows, Version 1.076. ORTEP-3 for Windows-a version of ORTEP-III with a Graphical User Interface (GUI). J. Appl. Crystallogr. 1997, 30, 565.

(C) 2011 by the authors; licensee MDPI, Basel, Switzerland. This article is an open access article distributed under the terms and conditions of the Creative Commons Attribution license (http://creativecommons.org/licenses/by/3.0/). 